\title{
ESTIMATING STORAGE CAPACITY LOSS DUE TO SEDIMENTATION FOR MURUM RESERVOIR IN SARAWAK, MALAYSIA
}

\author{
JOYCE JANGGU ${ }^{1}$, SUSIE NADYA ${ }^{1} \&$ MUBASHER HUSSAIN ${ }^{2}$ \\ ${ }^{1}$ Sarawak Energy Berhad, Malaysia \\ ${ }^{2}$ Stantec UK Limited, UK
}

\begin{abstract}
Sarawak state of Malaysia has three large storage dams conserving fresh water for the mega hydro plants, i.e. Bakun Hydroelectric Plant (HEP) (2,400 MW), Murum HEP (944 MW) and Batang Ai HEP (108 MW). Murum HEP and Bakun HEP are cascaded development where Murum HEP regulates about $20 \%$ of Bakun HEP catchment. The catchment of Bakun HEP is experiencing extensive land development through logging activities and palm oil plantation. Due to these activities, the rate of sedimentation should be assessed in all major river tributaries flowing into Murum Reservoir. The Hydro team has been conducting sedimentation sampling in these river tributaries over the last few years and the total suspended sediment load in the river flow is being analysed. The objective of this study is to estimate the storage capacity loss at Murum reservoir by analysing the sediment build-up rate along with time and the expected reservoir life by calculating the sediment trap efficiency for Murum reservoir. The results will also help to highlight the sedimentation issue at Murum reservoir.

Keywords: sedimentation rate, storage capacity loss, reservoir, hydroelectric plant, dam, Bakun HEP, Murum HEP, Sarawak, Malaysia.
\end{abstract}

\section{INTRODUCTION}

Sarawak state of Malaysia has three large storage dams conserving fresh water for the mega hydro plants i.e. Bakun Hydroelectric Plant (HEP) (2,400 MW), Murum HEP (944 MW) and Batang Ai HEP (108 MW). Murum and Bakun HEP are cascaded development where Murum HEP regulates about $20 \%$ of the Bakun HEP catchment. The catchment of Murum HEP is experiencing some land development through logging activities and palm oil plantation. Due to these activities, the rate of sedimentation should be assessed in all major river tributaries flowing into Murum Reservoir. The Hydro Department team has been conducting sedimentation sampling in the river tributaries of Murum Reservoir since 2015 and the total suspended sediment load in the river flow is being analysed. The objective of this study is to estimate the storage capacity loss at Murum reservoir by analysing the sediment build-up rate along with time and the expected reservoir life by calculating the sediment trap efficiency for Murum reservoir. The results will also help to highlight the sedimentation issue at Murum reservoir.

It is estimated that after the 100 years of operation, the reservoir storage would decrease by $1.6 \%$ adopting Churchill curve method and $1.8 \%$ decrease in storage loss under Brune Envelop Curve method. The Churchill curve method estimated sediment volume of 150 million cubic metre (MCM) to be deposit in Murum Reservoir in 100 years while Brune Envelop Curve method estimated $165 \mathrm{MCM}$ to be deposit within the same period. The sediment build-up rate for Murum reservoir is very low compared to the average global water storage loss of $1 \%$ per year due to sedimentation in the storage facilities [1]. However, it is recommended to implement a catchment management plan to minimise the sedimentation and erosion in the Murum catchment. 


\section{BACKGROUND}

Dams interrupt the continuity of sediment transport through rivers resulting in reservoir storage loss [2]. Reservoir sedimentation is a critical issue worldwide causing a reduction is storage volumes and reservoir efficiency [3]. Sediment transport studies are essential to estimate the total sediment inflow to the Dam, trap efficiency of the reservoir, trapped sediment load and the life of the reservoir with and without flushing or sluicing option [4]. Moreover, sediment study is essential to explore ways to minimize the entry of sediments into the reservoir and techniques to de-silt the deposited sediments to enhance its life [5].

The loss of storage due to sedimentation exacerbates the problem of providing enough storage for rising population with rising aspiration and standards. Annual reservoir storage loss due to sedimentation in United States is $0.22 \%$ while $2.3 \%$ in China, which is higher than the global average reservoir storage loss [6], [7]. The 20th century was concerned with the development of reservoir storage; more emphasis will be required in the 21 st century on the conservation of storage and hence sediment management has become crucial.

Three strategies can be used to control reservoir sedimentation. First, sediment yield delivered from tributary basins can be reduced by erosion control or upstream sediment traps. This includes watershed management practices [8]. Second, sediments may be removed by dredging [9]. However, high costs and environmental consequences of large-scale spoil disposal are major obstacles to large scale dredging. Third, hydraulic regime can be designed to route inflowing sediment through or around the storage pool to minimize deposition, and to remobilize and flush out previously deposited sediments [10].

Murum Reservoir is the second largest storage reservoir in Malaysia after the Bakun Reservoir with a total storage capacity of 9,247 million cubic metre (MCM) at its full supply level of 540 masl. The reservoir filling was started in September 2013 and it was fully impounded in November 2014. There are two main river tributaries, Plieran River and Danum River contributing to the Murum Reservoir with other small river tributaries. A catchment of $2,750 \mathrm{~km}^{2}$ feeds into the Murum Reservoir. The location of Murum and Bakun HEP is illustrated in Fig. 1 and the location of Plieran and Danum rivers is shown in Fig. 2.

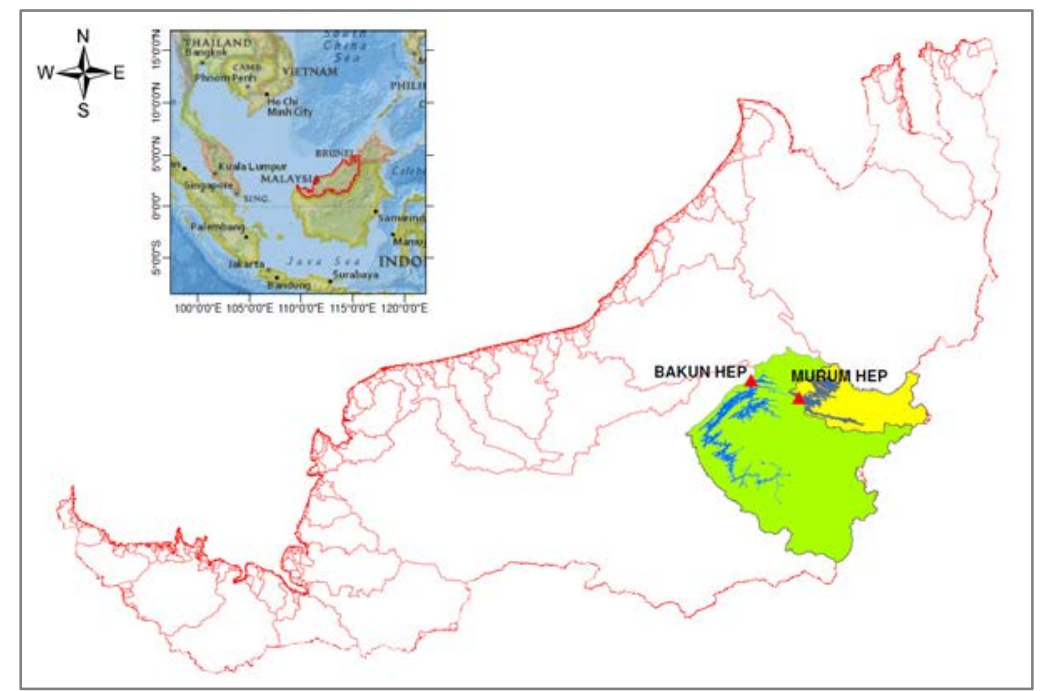

Figure 1: Location of Murum and Bakun HEP on the Malaysian island of Borneo. 


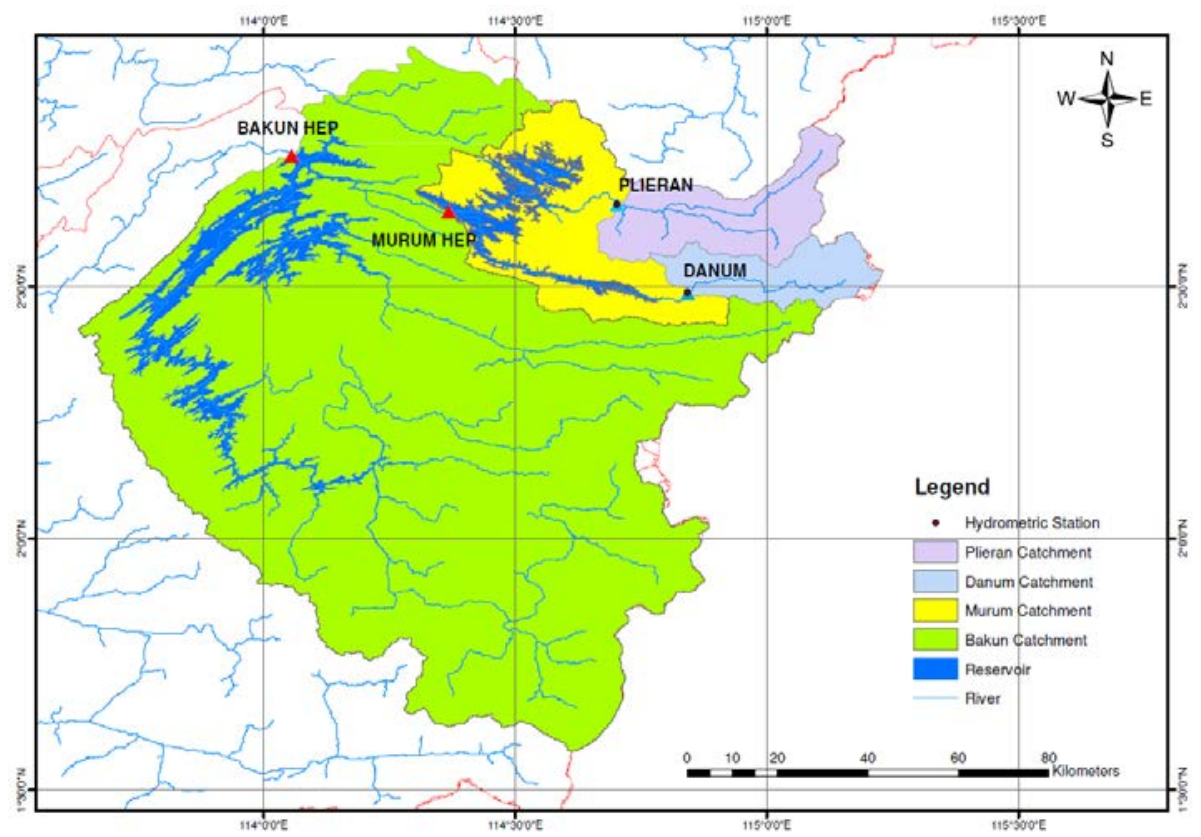

Figure 2: Location of Plieran and Danum hydrometric stations and their catchment boundaries.

\section{MATERIALS AND METHODS}

The methodology of this study is summarized in Fig. 3.

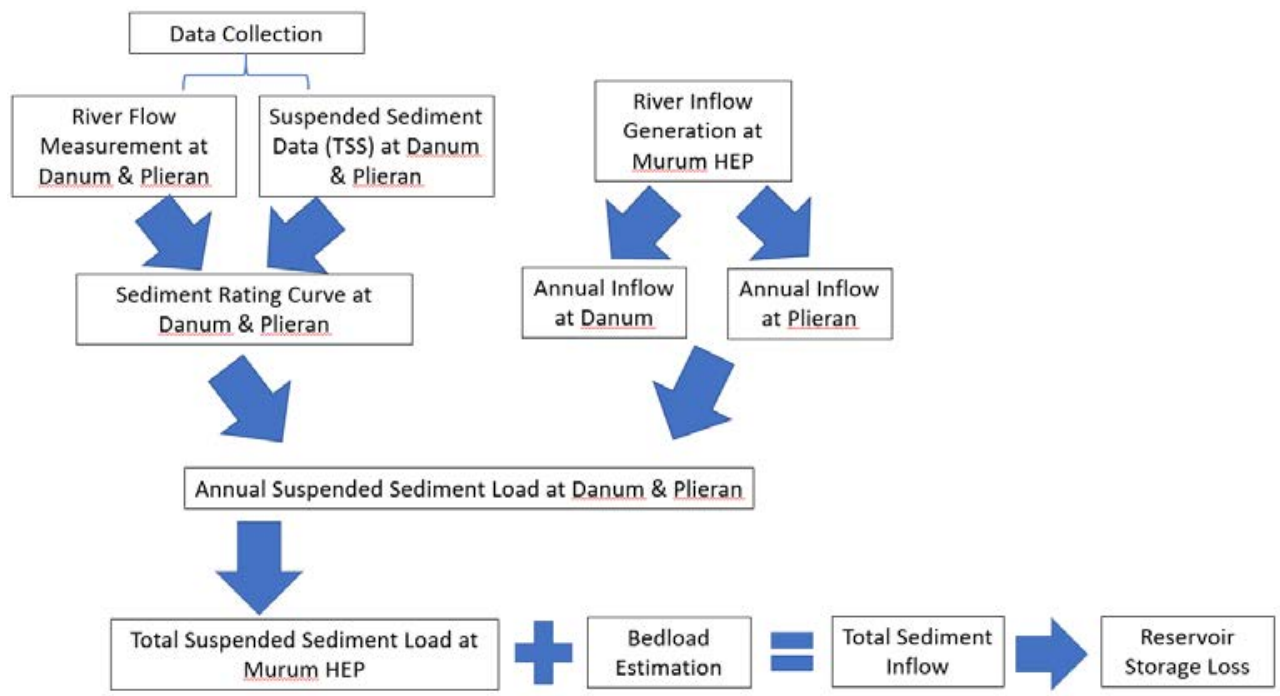

Figure 3: Summary of methods applied in this study. 


\subsection{Data collection}

For this study, the river inflow and suspended sediment concentration data was collected nearby the hydrological station of Plieran and Danum; both of which are upstream river tributaries contributing to Murum Reservoir. The location of the hydrometric stations are as shown in Fig. 2.

The river inflow was measured by using an Acoustic Doppler Current profiler (ADCP); in particular, the Sontek RiverSurveyor M9 as shown in Fig. 4.

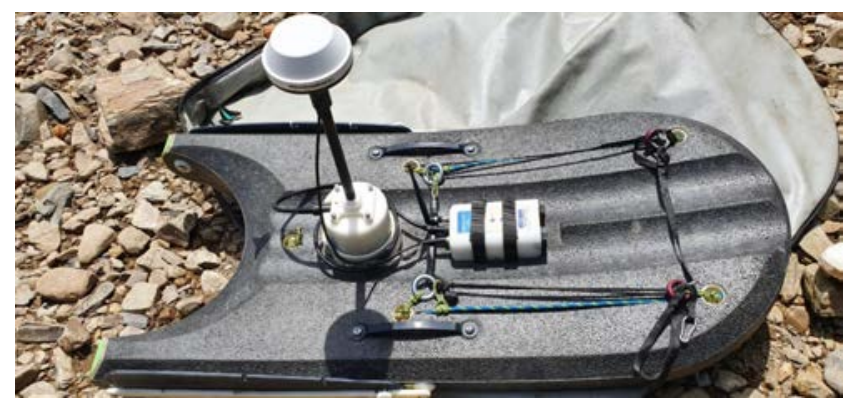

Figure 4: Sontek RiverSurveyor M9 used for inflow measurement.

\subsection{River inflows generation}

Hydrological model was established for the Bakun catchment to simulate daily river inflows at Bakun HEP. A rainfall-runoff model was developed using the observed rainfall data from the rainfall gauges in the Bakun catchment. The model was calibrated with the recorded river inflows at the Bakun Dam. After the calibration, the model was run for the Murum HEP to generate long term daily inflows at Murum Dam. After the generation of inflows at Murum Dam, the inflows were scaled to Plieran and Danum hydrometric stations as these two stations are the location points for the monitoring of suspended sedimentation data to Murum Reservoir. The inflows at Plieran and Danum were derived from the Murum Dam using the scale factor derived from the catchment area ratio.

\subsection{Suspended sediment}

Suspended sediment data is being collected at Plieran and Danum hydrometric stations since 2015. 42 water samples were collected from the Plieran and 50 samples from the Danum during the period of 2015 to 2019 . River water samples were collected using a $500 \mathrm{ml}$ water bottle at a depth of about $30 \mathrm{~cm}$ below the water surface and samples were taken in the middle of the river.

Total suspended solids (TSS) in mg/l and part per million (PPM) were analysed for each water sample to assess the suspended sediment concentration in water. With the TSS results for both stations, the suspended sediment concentration rating curves were developed.

\subsection{Suspended sediment rating curves}

With the TSS results for both Plieran and Danum hydrometric gauging stations, the suspended sediment concentration rating curves were developed as shown in Figs 5 and 6. 
These suspended sediment rating curves were further used to calculate the suspended sediment load at both rivers.

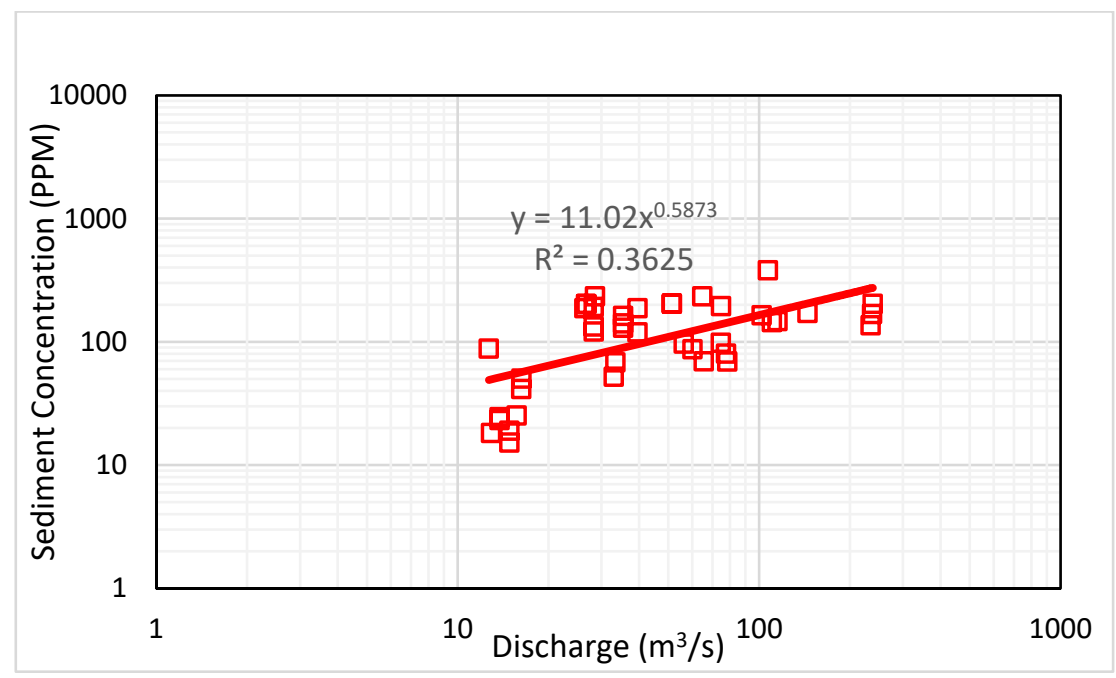

Figure 5: Suspended sediment concentration rating curve for Plieran.

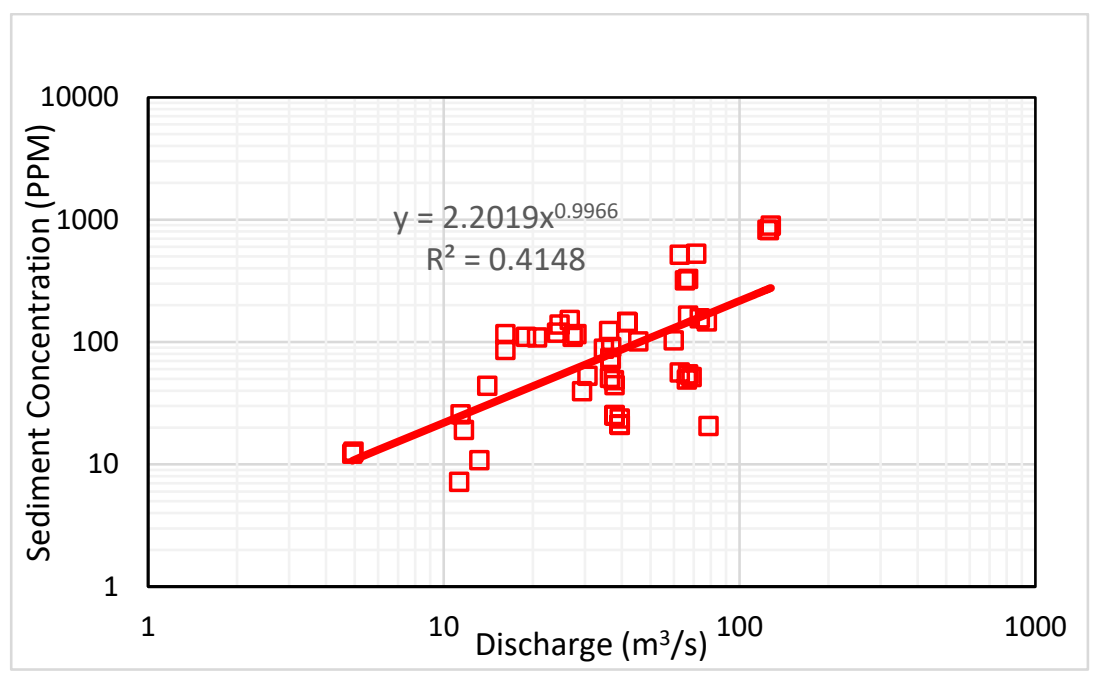

Figure 6: Suspended sediment concentration rating curve for Danum.

\subsection{Total suspended sediment load}

Annual suspended sediment load at Plieran and Danum were calculated using the sediment rating curves derived for each station and using the long-term daily inflows at both stations. To calculate the suspended sediment load at Murum Dam, the following relationship was 
used based on the proportionate of each river contributing to the Murum catchment, whereby $\mathrm{Q}_{\mathrm{s}}$ represents suspended sediment load:

$$
\left(Q_{s}\right)_{\text {Murum }}=0.56\left(Q_{S}\right)_{\text {Plieran }}+0.44\left(Q_{s}\right)_{\text {Danum }}
$$

\subsection{Bed load estimation}

Currently, the bed load sample at Murum, Plieran and Danum River has not been extracted yet. Therefore, the bed load was estimated using the Modified Einstein procedures for unmeasured sediment load [11].

Modified Einstein procedure is a useful guide for evaluating the unmeasured sediment load. The bed load estimation is shown in Table 1. Five conditions; Condition 1, 2, 3, 4 and 5 , are given for defining bed load depending upon suspended sediment concentration and size analysis of stream bed and suspended materials.

According to the Modified Einstein procedure, condition 4 of the Table 1 of bed load correction is very close to the site conditions in which stream bed material is composed of compacted clay, gravel, cobbles or boulders.

Therefore, the adopted percentage of bedload estimation for Murum reservoir according to the Modified Einstein procedure is a conservative value of $15 \%$ the total suspended load.

Table 1: Bed load estimation.

\begin{tabular}{|c|c|c|c|c|}
\hline Condition & $\begin{array}{c}\text { Suspended } \\
\text { sediment } \\
\text { concentration } \\
(\mathrm{mg} / \mathrm{L})\end{array}$ & $\begin{array}{c}\text { Stream bed } \\
\text { material }\end{array}$ & $\begin{array}{c}\text { Texture of } \\
\text { suspended } \\
\text { material }\end{array}$ & $\begin{array}{c}\text { Percentage bed } \\
\text { load in terms of } \\
\text { suspended load }\end{array}$ \\
\hline${ }^{1} 1$ & $<1,000$ & Sand & $\begin{array}{c}20 \% \text { to } 50 \% \\
\text { sand }\end{array}$ & 25 to 150 \\
\hline 12 & 1,000 to 7,500 & $\begin{array}{c}20 \% \text { to } 50 \% \\
\text { sand }\end{array}$ & 10 to 35 \\
\hline 3 & $>7,500$ & Sand & $\begin{array}{c}20 \% \text { to } 50 \% \\
\text { sand }\end{array}$ & 5 \\
\hline 24 & Any concentration & $\begin{array}{c}\text { Compacted clay, } \\
\text { gravel, cobbles, } \\
\text { or boulders }\end{array}$ & $\begin{array}{c}\text { Up to } 25 \% \\
\text { sand }\end{array}$ & 5 to 15 \\
\hline 5 & Any concentration & Clay and silt & No sand & $<2$ \\
\hline
\end{tabular}

Notes:

${ }^{1}$ Special sampling program for Modified Einstein computations required under these conditions.

${ }^{2} \mathrm{~A}$ bed load sampler such as the Helley-Smith bedload sampler may be used, or computations made by use of two or more of the bedload equations when bed material is gravel or cobble size.

\subsection{Total sediment inflow}

Finally, the daily total sediment loads $\left(Q S_{\text {total }}\right)$ to the Murum Dam were computed by adding the bed load, as estimated in Section 3.6, to the suspended sediment load and according to eqn (2):

$$
Q S_{\text {total }}=Q_{s}+Q_{\text {bedload }}=1.15(Q)_{s}
$$




\subsection{Reservoir storage loss}

Trap efficiency of a reservoir primarily depends upon fall velocity of sediment particle and on rate of flow through reservoir. Particle fall velocity may be influenced by the size and shape of particles, viscosity of water, and the chemical composition of water.

Methods for estimating reservoir trap efficiency are empirically based on measured sediment deposits in a large number of reservoirs. The famous methods are M. A. Churchill method [12] and Brune Envelope Curve method [13]. M. A. Churchill developed a relationship between percentage of incoming sediment passing through a reservoir and sedimentation index of reservoir. For this study, the trap efficiency of Murum reservoir is computed using the Churchill curve. Using the trap efficiency results from the Churchill curve, Murum reservoir storage loss is computed using both Churchill curve and Brune Envelope method. Results are compared and presented in Section 4.4.

\section{RESULTS AND DISCUSSION}

\subsection{River inflows generation}

According to the method defined in Section 3.2, Figs 7-9 shows the annual inflows at Murum Dam, Plieran and Danum hydrometric stations. The average inflow at Murum Dam is 264 $\mathrm{m}^{3} / \mathrm{s}$, whereas Plieran's average inflow is $75 \mathrm{~m}^{3} / \mathrm{s}$ and Danum's average inflow is $50 \mathrm{~m}^{3} / \mathrm{s}$. The average inflows are denoted in Figs 7-9.

\subsection{Total suspended sediment load}

Using the derived rating curves in Section 3.4, the mean annual suspended sediment load at Plieran was calculated as 0.40 million tonne per year; whereas at Danum it was estimated as 0.35 million tonne per year as shown in Figs 10 and 11.

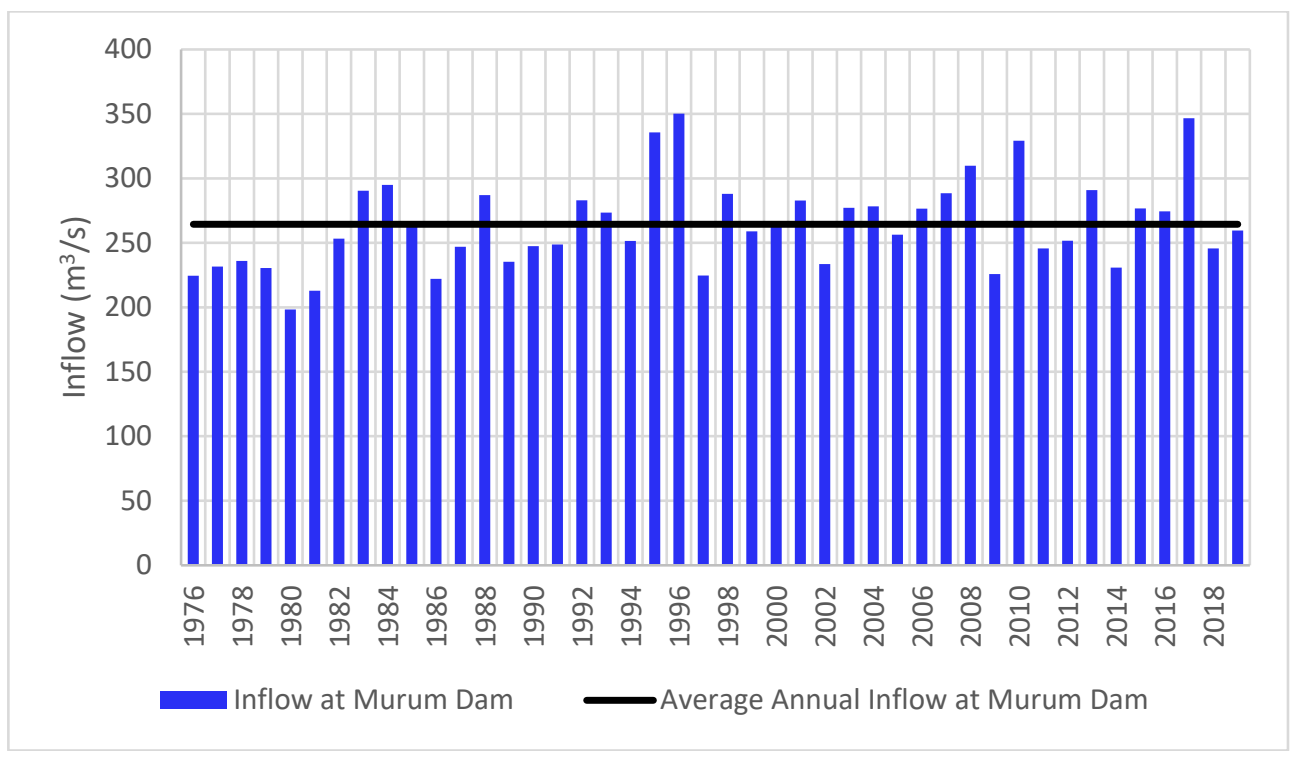

Figure 7: Annual inflows at Murum Dam. 


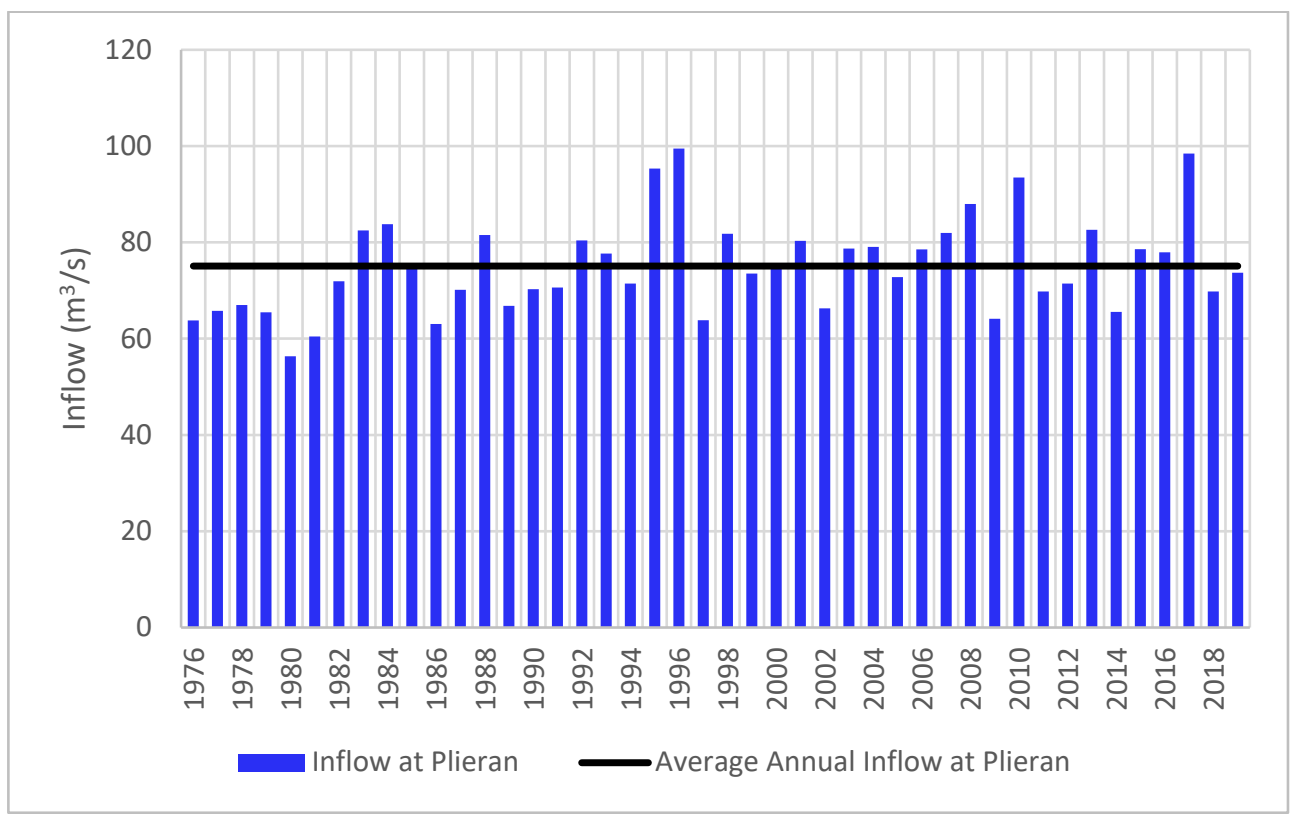

Figure 8: Annual inflows at Plieran.

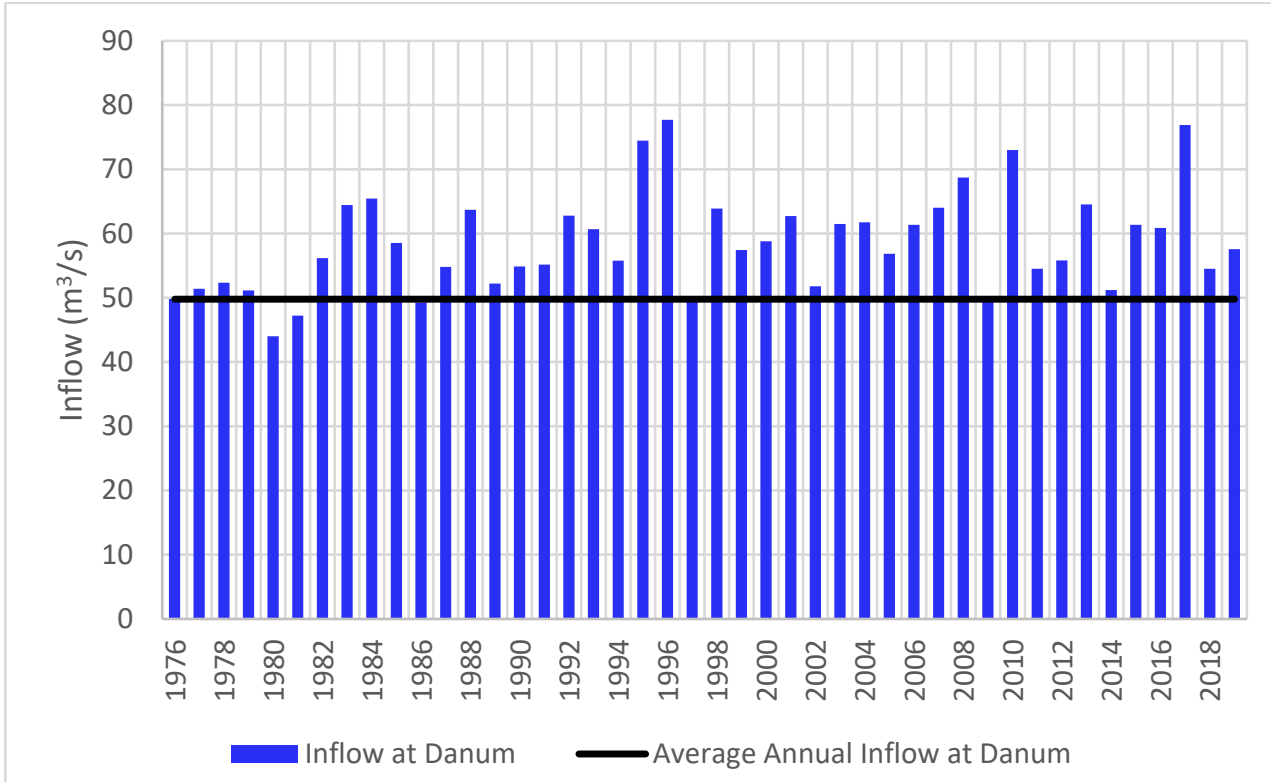

Figure 9: Annual inflows at Danum. 


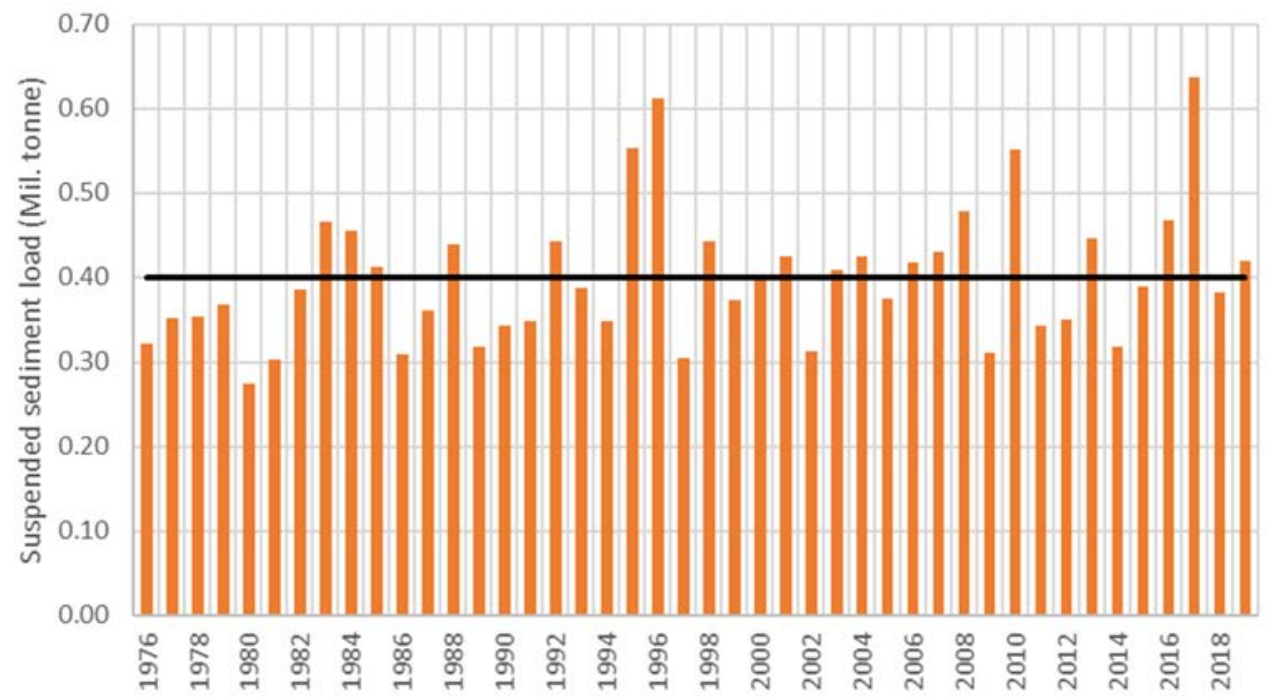

Figure 10: Annual suspended sediment load at Plieran.

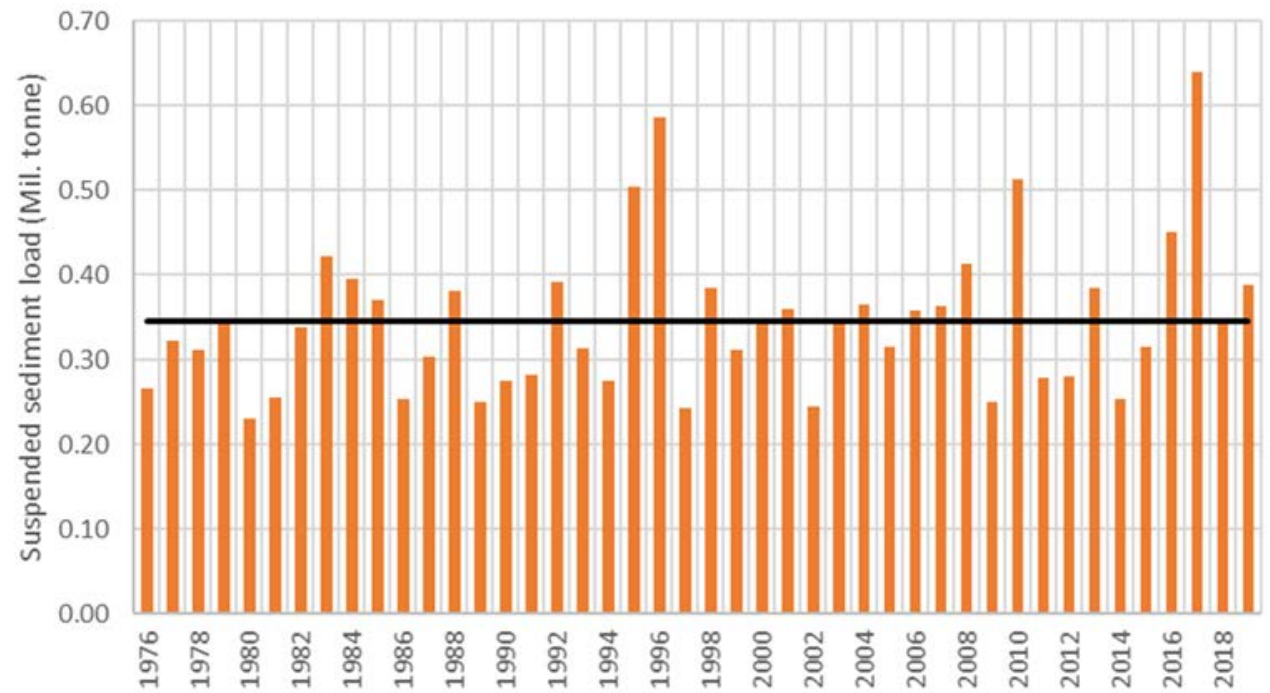

Figure 11: Annual suspended sediment load at Danum.

Using eqn (1) as per Section 3.5, the mean annual suspended sediment load at Murum Dam was calculated as 1.47 million tonne per year as shown in Fig. 12. 


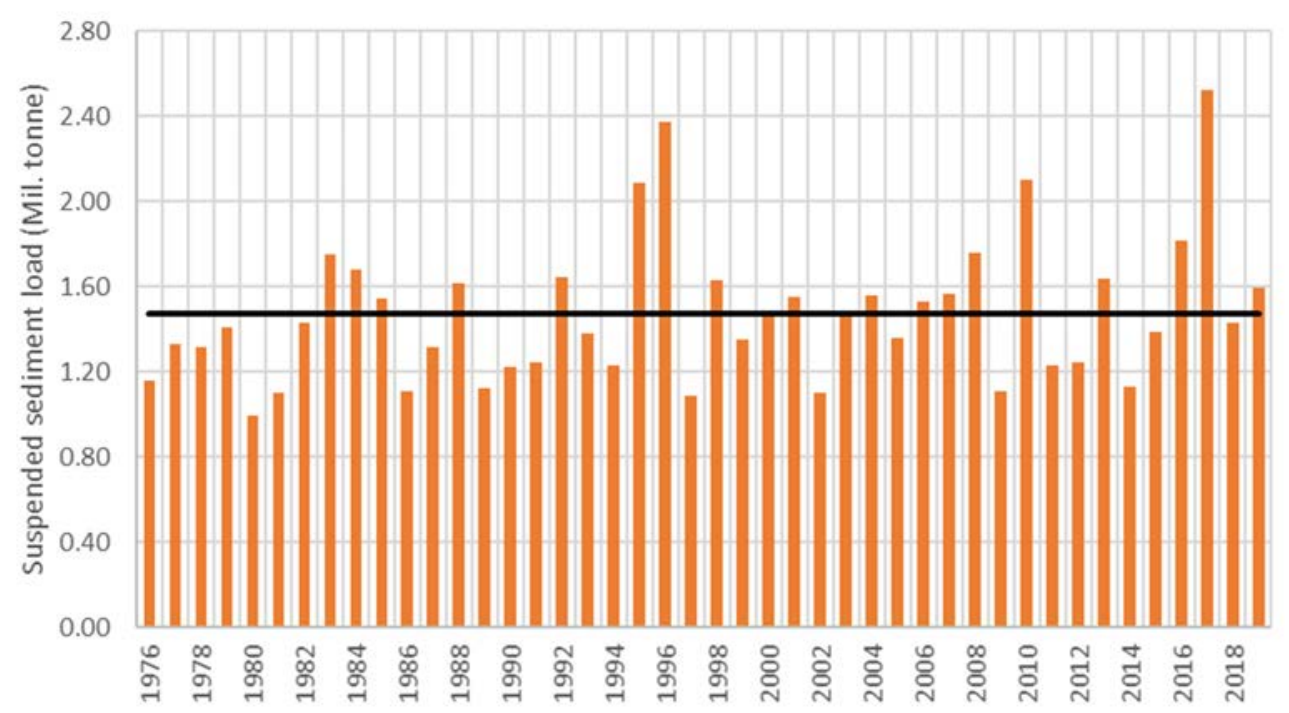

Figure 12: Annual suspended sediment load at Murum Dam.

\subsection{Total sediment inflow}

The total sediment inflow was calculated according to eqn (2) in Section 3.7. Based on the equation, the total average annual sediment inflow to Murum reservoir comes out to 1.69 million tonnes.

\subsection{Reservoir storage loss}

The Murum reservoir capacity is 9,247 million cubic metre (MCM), whereas the average annual inflow to Murum Dam is about $8,338 \mathrm{MCM}$, ratio between the two is 1.11. Consulting Churchill curve [12], trap efficiency comes out equal to $89 \%$ while consulting Brune envelop curve method [13], trap efficiency comes out as $98 \%$. The efficiency does not reduce with the increase in age of reservoir as the storage loss does not reduce significantly over the period of 1,000 years. The comparison of reservoir storage loss estimated by both methods is plotted in Fig. 13.

According to the results in Fig. 13, it is estimated that after 100 years of operation, the reservoir storage would decrease by $1.6 \%$ when adopting Churchill curve and $1.8 \%$ when adopting Brune Envelop Curve method; less than 2\% over a period of 100 years of operation and about less than $0.02 \%$ annual loss rate, which is about the same as concluded in [14]. On this basis, Murum's reservoir storage loss is low compared to the average global water storage loss of $0.5 \%$ to $1 \%$ per year due to sedimentation in storage facilities [1]. Compared to a study in Central United States of America, the reservoirs have lost approximately $17 \%$ of their original capacity over a period of 52 years, with the highest single reservoir loss of $45 \%$ [15]. This equates to an annual loss rate of $0.84 \%$; much higher compared to Murum reservoir's annual loss rate of less $0.02 \%$. Similarly in Brazil, a study found that the storage capacity of the reservoirs in the state of Ceará is experiencing a storage loss of $0.2 \%$ per year [16]. Both studies in [15] and [16] concluded that the major cause for reservoir storage loss is due to high sedimentation. 


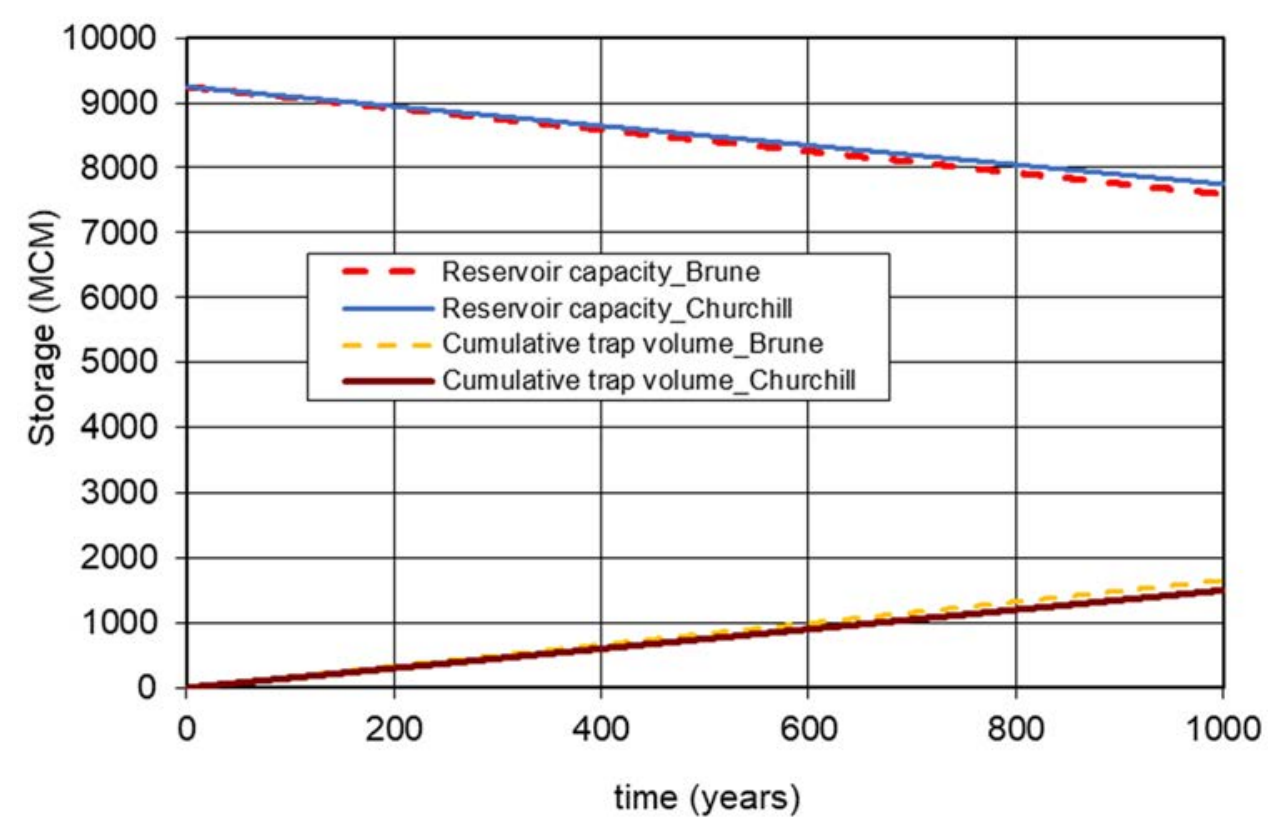

Figure 13: Reservoir storage loss and sediment build-up in Murum reservoir.

The Churchill curve method estimated a sediment volume of $150 \mathrm{MCM}$ to be deposited in Murum reservoir over a period of 100 years while Brune Envelop Curve method estimated $165 \mathrm{MCM}$ to be deposit in Murum Reservoir over the same time period. Using a basis of 1,000 years of operation, the storage loss for Murum Reservoir is expected to be $16 \%$ and $18 \%$ using the Churchill and Brune Envelop Curve method respectively.

\section{CONCLUSION AND RECOMMENDATIONS}

It is concluded that the storage loss of Murum Reservoir due to sedimentation is less than $2 \%$ over a period of 100 years of operation; about less than $0.02 \%$ annual loss rate and similar to what is concluded in [14]. Compared to the average global water storage loss [1], Murum's reservoir storage loss is low.

The estimation in this study is based on a short record of sedimentation data and it is recommended to continue with water sampling to develop matured sediment rating curves at both sites to improve the understanding on the suspended load concentration in the rivers. It is also recommended to conduct bed load sampling by using a sampler such as the HelleySmith bedload sampler to improve the understanding on the bed load contribution to the sedimentation in the reservoir.

This study used the empirical method to estimate the sedimentation in Murum Reservoir and it is recommended to develop a physical based sedimentation model to understand the catchment behaviour on the sedimentation and erosion in more detail.

It is also recommended to implement a catchment management plan to minimise the sedimentation and erosion in Murum catchment, as well as understanding land-use factor for land-use mapping to identify critical areas prone to high sedimentation rate. In the long-term, it is recommended to manage reservoir sediments by means of bypassing sediment around the reservoir, sluicing or drawdown flushing [2]. 


\section{REFERENCES}

[1] Schellenberg, G., Donelly, C.R., Holder, C. \& Ahsan, R., Dealing with sediment: Effects on dams and hydropower generation. Hydro Review, 25(1), 2017.

[2] Kondolf, G.M. et al., Sustainable sediment management in reservoirs and regulated rivers: Experiences from five continents. Earth's Future, 2(5), pp. 256-280, 2014.

[3] Reisenbüchler, M., Bui, M.D. \& Rutschmann, P., Reservoir sediment management using artificial neural networks: A case study of the lower section of the Alpine Saalach river. Water, 13(6), 2021.

[4] Gunawan, T.A., Daud, A., Haki, H. \& Sarino, The estimation of total sediments load in river tributary for sustainable resources management. IOP Conference Series: Earth and Environmental Science, IOP Publishing, 2019.

[5] Dargahi, B., Reservoir sedimentation. Encyclopedia of Lakes and Reservoirs, eds L. Bengtsson, R.W. Herschy \& R.W. Fairbridge, Springer Netherlands: Dordrecht, pp. 628-649, 2012.

[6] Tan, G., Review and improvement of conventional models for reservoir sediment trapping efficiency. Heliyon, 5, 2019.

[7] Jiang, N. \& Fu, L., Problems of reservoir sedimentation in China. Chinese Geographical Science, 8(2), pp. 117-125, 1998.

[8] Xin, Z., Ran, L. \& Lu, X.X., Soil erosion control and sediment load reduction in the Loess Plateau: Policy perspectives. International Journal of Water Resources Development, 28(2), pp. 325-341, 2012.

[9] Peterson, S.A. Sediment removal as a lake restoration technique. EPA-600/3-81-013, 1981.

[10] van Rijn, L.C. Sedimentation of sand and mud in reservoirs in rivers. 2013.

[11] Design of Small Dams, ed. Interior USDot, Bureau of Reclamation, United States Government Printing Office: Denver, Colorado, 1987.

[12] Churchill, M.A. (ed.), Discussion of analysis and use of reservoir sedimentation data, by L.C. Gottschalk. Proceedings of Federal Interagency Sedimentation Conference, Denver, Colorado, Jan. 1948.

[13] Brune, M.G., Trap efficiency of reservoirs. Transactions of American Geophysical Union, 34(3), 1953.

[14] Electrowatt. Murum Hydroelectric Project - Feasibility Study. 1994.

[15] Rahmani, V. et al., Examining storage capacity loss and sedimentation rate of large reservoirs in the Central U.S. Great Plains. Water, 10(2), 2018.

[16] De Araújo, J.C., Güntner, A. \& Bronstert, A., Loss of reservoir volume by sediment deposition and its impact on water availability in semiarid Brazil. Hydrological Sciences Journal, 51(1), pp. 157-170, 2010. 